\title{
Examining the Determinants of Privatization: The ASEAN Context
}

\author{
Chotiphun Tiaviwat \\ Doctor of Philosophy in Public Policy and Administration Program \\ Graduate School of Public Administration \\ National Institute of Development Administration, Bangkok, Thailand \\ E-mail: chotiphun.tia@stu.nida.ac.th
}

Received: June 15, 2020 Accepted: June 30, 2020 Online published: July 2, 2020

doi:10.5296/jpag.v10i2.17188～URL: https://doi.org/10.5296/jpag.v10i2.17188

\begin{abstract}
This paper examines the economic, political, and institutional determinants of the propensity of privatization, as well as the sensitivity of privatization, in the Association of Southeast Asian Nations (ASEAN) context over the observation period from 1988 to 2008, with the Asian Financial Crisis being the median point of the observation period. This is particularly to investigate the organic progression of the privatization of ASEAN nations as an isolated endogenous phenomenon. This paper, using a two-stage quantitative technique, aims to exhibit the novel, and to a degree inventive, insights that are unique to the context of ASEAN, as well as to identify the potential policy implications directed towards how ASEAN policymakers may steer their national development policies to manufacture the constructive economic, political, and institutional conditions needed to foster privatization processes. The findings indicate that GDP per capita, current account balance, and stock market capitalization are statistically the key moving parts that contribute to the propensity of privatization, as well as the sensitivity of privatization, in the ASEAN context.
\end{abstract}

Keywords: privatization, ASEAN, public policy, new public management, public administration, economics, politics, institutions

\section{Introduction}

Privatization is generally accepted as means to improve the economic efficiencies, via the conception of Pareto improvements, of State-Own Enterprises (SOEs) as well as the general welfare of markets. Yet, the pursuit of privatization should not be assessed merely in terms of potential revenues raised by governments from SOEs divestures but also by the impact of privatization on the economic, political, and institutional counterparts. 
To be more precise, the principal force driving privatization was originally the bureaucratic inefficiencies of SOEs. This school of thought focuses on SOEs acting based on its own utility function - ideally, the primary objective of firms is to maximize profits and minimize production cost; hence, these firms will focus merely on optimizing specific moving parts as well as key stakeholders, typically the managers and the shareholders, rather than engaging in social services beneficial to the general public as a whole. Priorities tend to change from socio-economic and political benefits to profit maximization, a side effect of changing SOEs to private sectors (Megginson, 2017). This assumes and suggests that the decision to privatize is rather a micro level discretionary course of action of the managers and actors within the state enterprise itself, and the notion of public efficiency may be disregarded. This, at a mere glance, may deceptively exhibit a destructive rather than a constructive resonance. Nevertheless, privatization is proving to be more active in more globalized economies. According to Beck, Demirgüç-Kunt, and Levine (1999), the constructive economic effect of privatization is already being felt worldwide as, converting SOEs into private companies improved them both financially and operationally, and the spillover effect extends across all moving functions of the economies, especially managerial efficiency as well as technological productivity of the privatized entities induced by the private sector to stay competitive.

The principal focus of this paper is to examine the economic, political, and institutional determinants of privatization in developing countries in Southeast Asia. Before one can comprehend the dynamics of privatization as a policy tool, one must understand the extent of the essential key moving parts of the driving forces of such a tool. If privatization is a merely micro level natural phenomenon with the decision to privatize rather on an intra-enterprise level where such are discretionary decisions are made by SOEs managers and actors within the SOEs itself as a means to optimize the firms' multifaceted utility functions, policy making on a broad macro level may not be as effective in influencing privatization as a means to foster growth and reform on a macro level. On the other hand, the decision to privatize may also be viewed as a natural progressive series of managerial responses to macro broad based levels of economic, institutional, political conditions. If the latter is the case, macro level policy implementations will have an effect and can influence privatization.

This study will merely focus on developing countries in southeast Asia as they display more homogeneous levels of economic, institutional, and political environments that differ substantially from those of developed countries in Southeast Asia (Boubakr \& Cosset, 2011).

The study uses quantitative techniques to investigate the underlying determinants that statistically contribute to the process of privatization in Southeast Asia, specifically, what triggers the decision to privatize (privatization propensity) as well as to understand how the scale of privatization collides with its determinants (privatization sensitivity). A multinational empirical study of the determinants of privatization propensity as well as sensitivity, and the use of quantitative techniques from developing economies in Southeast Asia, will allow one to draw isolated novel insights that are unique to the context of the Association of Southeast Asian Nation (ASEAN) as well as to identify potential policy implications vis-à-vis how ASEAN policymakers may steer their national development plans towards a sustainable privatization process (Corsetti, Pesenti \& Roubini, 1999; Doyle, 2012). 
The statistical discovery of this study will be significant in the overall understanding of privatization in Southeast Asia, both as a reform measure and the furtherance of public and private interests. The examination of privatization achievements in developed economies based on the empirical literature provide exemplary models for us to examine the driving forces of privatization in Southeast Asia as a unique phenomenon in this study (Siniscalco \& Bortolotti, 2011).

More precisely, the central agendas that guide this paper are as follows:

\section{Research Questions:}

Question 1: In what ways do economic, political, and institutional determinants contribute to ASEAN government's decisions to privatize (the propensity of privatization)?

Question 2: How do economic, political, and institutional determinants define subsequent decisions on how much to privatize (the sensitivity of privatization)?

Question 3: What was the organic progression of privatization as a reform measure in ASEAN vs ASEAN plus six (ASEAN+6)?

\section{Research Objectives:}

Objective 1: To examine the initial decisions for governments to privatize SOEs in relation to their economic, political, and institutional determinants.

Objective 2: To identify the scale-of-privatization statistical variants in relation to their economic, political, and institutional determinants.

Objective 3: To identify the changes in statistical variants between ASEAN and ASEAN plus six $(A S E A N+6)$.

Understanding the mechanisms behind privatization will also allow governments to make wise public and fiscal decisions in order to maintain and improve public services and assets (Gupta, 2008). This includes fostering the political, institutional, and economic ecosystems as devices to manufacture high rates of public, and social, and economic efficiency through privatization (Gupta, 2008; Gwartney, Lawson \& Norton, 2008). A thorough analysis of the key components of privatization is an essential prerequisite compendium for policymakers in Southeast Asia, as well as for providing an original guidebook encompassing reform policies and measures surrounding privatization programs that are unique and most appropriate to the ASEAN context.

This paper will assess and analyze the generally accepted concept of privatization as a phenomenon and study will review much of what is already known about the economic, political, and institutional determinants of privatization relying upon the body of knowledge obtained from existing empirical studies and literature. This study then examines the ASEAN context during the observation periods from 1988 to 2008 with the median point of the observation period at the peak of the Asian Financial Crisis, with the ambition to understand precisely the contributing endogenous causes and effects as a frame of references for changes in economic, political, and institutional conditions that prominently influence privatization processes in ASEAN. The scope is to examine privatization as an isolated phenomenon 
applied to Southeast Asian countries, specifically, the developing economies in Southeast Asia - as there are no comparative studies to date that capture, on an isolated basis, the natural progression of privatization of ASEAN nations.

The analysis is designed to determine the various and differing factors that influence privatization propensity as well as privatization sensitivity via employing a Probit model and a fixed effects regression model respectively. More precisely, the study's framework is modelled as a two-step process, considering both the decision to privatize (privatization propensity) and the subsequent decisions concerning the scale of privatization (privatization sensitivity). In conducting this analysis, we will principally rely upon the World Bank's Privatization Database (World Bank 2015) as a cross-national measurement of the revenue collected from state divestures.

\section{Empirical Background and Theoretical Constructs}

Beginning in the mid 1970s, public administration management became an area of focus in developed and, to a lesser extent, in developing countries. Contributors to this focus were particularly interested in creating a new ideology or vision for public administration management that incorporated private sector managerial concepts. Numerous scholars contributed to the evolution of the New Public Management (NPM) concept, prompting commentators to observe that this concept has variously been defined as a vision, an ideology or (more prosaically) a bundle of particular management approaches and techniques - many of them borrowed from the private, for-profit sector (Pollitt, 1994).

In a review of NPM initiatives adopted by Southeast Asian nations, Turner (2002) identified three sets of countries with a different appetite for NPM style reform: the enthusiastic proponents (Singapore and Malaysia), the cautious observers (the Philippines, Thailand, and Indonesia), and the remainder who understood and adopted little of NPM (Vietnam, Laos, and Cambodia). Some things have changed since Turner's study: in particular, Vietnam has adopted a much more ambitious public administration reform program, partly driven by the State's decision to embrace a socialist, market-driven economy within a centralized state management structure and partly because of the urging of international aid agencies desiring an accelerated liberalization program (Painter, 2004). Samaratunge, Alam, and Teicher (2008) observed that South Asian nations have selected reform programs that accommodate the short-term objectives of the ruling elites. Although international aid agencies have promoted reform and pro-market public sector policy changes, entrenched partisan politics has resisted comprehensive reforms in favor of the interests of the vested political and business elites (Haque, 2002a, 2002b).

The historical development of privatization suggested that it is an outgrowth of NPM ideology for more efficient governance. Although privatization is a constitutive element of NPM, there is no consensus on what privatization is designed to really accomplish, no one definition or single, uniform example that embodies a universal goal of privatization. However, there is a broad understanding of why central state and local governments globally are said to have resorted to privatization: private-sector delivery of services is considered to be more efficient than comparable government-provided services. Following this assumed competitive advantage of private-sector delivery, it has been argued in the literature that when 
governments are fiscally stressed, they are inclined to engage in privatization because privatization is a way to preserve the standard service level when government resources are strained (Haque, 1998). Hence the defining features of both privatization and NPM is the infusion of pareto efficiency principles. Pareto efficiency is an economic situation that occurs when improvements in one area result in a loss in another; thus, Pareto efficiency occurs when resources are most optimally used and it becomes impossible to make improvements in one area without having an offsetting loss in another area. Achieving Pareto efficiency is, or should be, the objective of an optimal government. In many respects, privatization as well as NPM has been viewed as a component of structural reform in both developed and developing economies during the past quarter century and a means in which to achieve Pareto efficiency. Specifically, this requires:

1. Striving for efficiency, in addition to effectiveness and equity, in the delivery of public services

2. Utilizing economic market models for political and administrative relationships; public choice, negotiated contracts, transaction costs, and principal-agent theory

3. Applying the concepts of competition, performance-based contracting, service delivery, customer satisfaction, market incentives and deregulation (Savas, 2000)

In mainstream NPM, privatization exhibits all of the similar characteristics. Public managers operating in this environment are introducing managed competition and are contracting competitively with the private sector to deliver services more efficiently and effectively. (Savas, 2000). It is evident that privatization has its roots in the conceptual framework of NPM.

However, why do governments privatize? The literature points to several political, economic, as well as institutional justifications for why governments choose to privatize (Feigenbaum \& Henig, 1994; Spulber \& Spiegel, 1997; Feigenbaum, Henig, \& Hamnett, 1998). Prominent among these is the political explanation that right-wing governments privatize in order to shrink the public sector and to encourage an "enterprise culture" (Studler, MacAllister, \& Ascui, 1990). The prime example is, of course, Thatcher's conservative leadership in the late 1970s and 1980s in the United Kingdom. There are certainly more politics at play here; large-scale privatization programs have often been associated with the leadership of democratic, "pro-market-oriented" politicians. A large-scale privatization program may therefore represents a strategy for switching to forms of 'populist capitalism' by creating a constituency of voters interested in the maximization of the value of state financial assets. Furthermore, political cycles shape privatization processes. The perception of control is important during election years; thus, the pace of privatization could slow down around elections for the following reasons: Initially, elections introduce uncertainty about the identity of winning governments, and the incumbent government may want to avoid leaving windfall privatization revenue to the opposition. A country's legal heritage as well as its governing system is also a component part of the political atmosphere. Generally, common law systems tend to provide greater protection of citizens' and investors' rights as well as enriching the business landscapes - the literature points to an extrapolation that a common law system will generate larger volumes of revenue from state divestures via privatization. 
An alternative dialogue for privatization focuses on the economic rather than the political consequences of privatization and includes both conservative and liberal policy makers. This explanation promotes privatization on the basis that policymakers should disregard the day-to-day operation of mundane public services and, instead, concentrate on establishing decentralization and efficiency as well as adopting privatization as means for economic stabilization (Lane, 2015). A theoretical analysis of macroeconomic implications of privatization is challenging because of the numerous of other potential influences privatization. There are theoretical models as well as empirical studies that link privatization to macroeconomic performances. The initial interaction between privatization and macroeconomics is derived from a scenario of macro instability; particularly when there are large budget deficits, low GDP, low GDP per capita, high unemployment rate, as well as deflation which tends to accelerate privatization endeavors (Boix, 1997; Brune \& Garrett, 2000; Biglaiser \& Danis, 2002). There is a natural correlation between a financially unhealthy public sector, a government's willingness to engage in reform efforts, and the political acceptability of such reform efforts. Hence, we may extrapolate that high public deficit via high public debt, as well as low tax revenue, induces expeditious public restructuring and reform (López-De-Silanes et al., 1997; Biglaiser \& Danis, 2002). We are thus prompted to examine the interaction between privatization and macroeconomic mechanisms as well as public and fiscal barometers of ASEAN nations. All things being equal, depressed GDP, GDP per capita, deflation, and high unemployment rate should result in privatization initiatives, allowing government to increase its spending capacity to help support economic stabilization in the short term and eliminate the need for future subsidies (Laffont \& Tirole 1993; Shleifer et al., 1998; Havrylyshyn \& McGettigan, 2000). Additionally, high fiscal deficit via high debt to GDP, and low tax revenue, should also result in the escalation of privatization via the inter-temporal budget constraint theory as a normative guidepost for privatization: privatization is recommended when it improves efficiency, as reflected in improvement in a government's net worth. However, governments also face a second budget constraint, which requires that in any given period all government spending must be financed. A change that permits privatization effectively softens this one-period budget constraint by providing an additional temporary source of financing. This suggests an additional motive for privatization, one that, given the short-term focus of policymakers, may more adequately capture the political enthusiasm for privatization (Schipke, 2001).

If $\mathrm{G}$ stands for government expenditure, $\mathrm{T}$ for taxes, $\mathrm{BD}$ for domestic non-bank borrowing, $\mathrm{BF}$ for foreign borrowing, NDCG for net credit to the government from the banking system, and PR for privatization proceeds, the one-period budget constraint can be expressed as follows:

$\mathrm{G}=\mathrm{T}+\mathrm{BD}+\mathrm{BF}+\mathrm{NDCG}+\mathrm{PR}$ (Schipke, 2001)

The inclusion of PR in the equation gives policymakers an additional choice in pursuing their policy objectives, irrespective of whether or not privatization will affect the inter-temporal budget constraint. Ceteris paribus, as a result of privatization, policymakers can:

1. Increase government expenditure on a temporary basis above and beyond what otherwise would be possible. If other sources of financing remain unchanged, an 
increase in government expenditure would allow governments to affect aggregate demand in a predetermined manner

2. Maintain a level of expenditure and hence avoid a politically adverse contraction, even in the light of a shortfall in any of the other sources of financing

3. Lower taxes; besides re-distributive effects that allow the government to target politically influential group in society, the government could use a privatization-financed reduction in taxes to stimulate aggregate demand. The latter, of course, requires that households be non-Ricardian (Schipke, 2001; Siniscalco et al., 2003)

4. Lower the recorded and publicly visible fiscal deficit by counting privatization proceeds as revenue equivalent

Institutions also play a big role in introducing and leading the ambition for privatization, especially the international financial institutions. The World Bank takes the lead in privatization, but the IMF has also cooperated closely. Drawing on the World Bank's experiences and recommendations, a majority of IMF-supported programs in recent decades have included some form of conditionality on privatization (Gupta, 2008; Stiglitz, 2009). Monitoring privatization in IMF-supported programs has emphasized on the processes and fiscal targets - there is scope for IMF conditionality to give more weight to privatization procedures where these have important fiscal and macroeconomic impacts. Similarly, these programs should, in some cases, give greater importance to the establishment of an appropriate regulatory environment within which privatized enterprises operate (Guislain, 1997; Stiglitz, 2009). The design of financial programs should include as broad a definition of privatization receipts as possible in the fiscal targets and quantitative performance criteria and consider the macroeconomic effects in assessing the use of privatization (Laffont \& Tirole, 1993; Shleifer et al., 1998; Djankov \& Murrell, 2000).

The nexus between privatization and globalization can likewise be demonstrated. Globalization usually improves the investment landscape via the flow of foreign capital as well as other forms of foreign participations, thus making sale of state assets more attractive for investors, domestic and foreign alike, and a better macroclimate for privatization. A study by Shahbaz, Mallick, Mahalik , and Hammoudeh (2017) argues that globalization is a powerful driver of institutional reforms as well as privatization, particularly in developing countries. Thus, globalization has important implications for the pace of privatization; it is important to capture the phenomena by controlling for trade liberalization and the level of capital mobility (Debab, 2011). Taken together, these variables capture the extent of a country's economic interdependence with the rest of the world. A study by Chinn and Ito (2008) suggests openness to trade via current account can be used to capture the degree of capital mobility and trade liberalization. Current account is a function of a country's balance of payments, the capital account, and the financial account. A country's current account can generally be expressed by the following formula:

$\mathrm{CA}=(\mathrm{X}-\mathrm{M})+\mathrm{NY}+\mathrm{NCT}$

Where $C A$ is the current account, $X$ and $M$ are respectively the export and import of goods and services, NY the net income from abroad, and NCT the net current transfer 
Foreign direct investment (FDI) is correspondingly an essential element of privatization via globalization. Since FDI enhances the competitiveness of the domestic economy, contributes to more skilled labor, and helps to import new technology, it should result in positive externalities on the macroclimate as well as the domestic ecosystem of a country. As a consequence, governments will have more incentives to privatize if the economy is more open to foreign investment. In the case of developing countries, the World Bank (2003) notes, for instance, that FDI has become the largest and most resilient form of capital flows (Sagarik, 2015). Specifically, robust FDI inflow will allow for larger absorptions of shares from sales of SOEs' divestures from higher purchasing power coming from foreign investors (Levine et al., 1999; Gbakou, Jallab, \& Sandretto, 2008; Boubakri, Cosset, Debab, Valery, 2009, 2011).

Stock market infrastructure, too, is an important constituent of privatization. The gauge of stock market infrastructure comes in form of size (market capitalization) and flow (market turnover). The maturity of the financial market infrastructure in the dimension of market capitalization and market turnover facilitates privatization activities (Pagano, 1993; Bekaert, 1997) via information aggregation (Grossman, 1976), monitoring of managers (Holmstrom and Tirole 1993; Jensen \& Meckling, 1996), regulations of enterprises (Faure-Grimaud, 1999), and providing the financial architectures needed for the complex as well as the high through-put operations required to execute extensive privatization transactions (Pagano, 1993).

\section{Framework and Research Methods}

\subsection{Data Analysis}

The statistical analysis will be divided into two stages. In the first stage, the determinants of the propensity to privatization via a Probit model are analyzed. In the second stage, the determinants of the sensitivity of privatization via the scale of revenues earned by the governments via a fixed effects regression model (FE regression model) are analyzed. A mediator variable will be generated from the first stage using the inverse mill ratio from the Probit model (Heckman 1979) and will be included as a controlled variable in the second stage FE regression. Intuitively, we extract from the statistical models, the initial stage involving what influences are key to the decisions to adopt privatization, followed by a second stage, involving an implicit breakdown into the sensitivity of the phenomenon (Boubakri, Cosset, \& Guedhami, 2005; Doyle, 2013)

The benefit of this approach is that many developing nations in ASEAN have never pursued privatizations at all. Without taking into consideration the profile of the countries that have never privatized, a statistical analysis would only capture limited variations of the phenomenon. Particularly, it may add statistical bias by inflating the importance of the attributes of countries that privatized while ignoring specific attributes of those that did not privatize (D'Souza \& Megginson, 2000). In order to correctly analyze both the propensity of privatization and the systematic relationship with the sensitivity of privatization, we hence begin by estimating a Probit model to analyze the propensity to privatize (Carter \& Signorino, 2010). Then later a mediator variable is included in the second stage of the FE regression statistical analysis as a control variable. 


\subsection{Dummy Variable Trap}

Political Preference variables are all dummy variables and are prone to a dummy variable trap, where data outputs are sometimes omitted. A dummy variable trap is a scenario in which independent variables are multicollinear - a scenario in which multiple variables are highly correlated. In our case, the dummy variables used for election, legal system, and government ideology may introduce multicollinearity noise into the model outputs. For instance, when a government is democratic (a binary input of one for the government ideology variable), there will likely be an election (a binary input of one for the election year variable) and vice versa when a government is undemocratic, or for instance a year with a coups d'état, there will be no election that year- two highly correlated political constructs. Additionally, the legal system variable may also introduce a statistical noise as the legal system of a country is typically unchanged throughout time via a constant input throughout a time series data set simply put, countries do not often change their legal system.

\subsection{Model Diagnostics and Cross-Validation}

Model diagnostics and cross-validation applies mainly to those models that will be utilized as a predictive as well as explanatory tool. Types of validation procedures include: external validation, where the predictive as well as the explanatory accuracy is determined by applying the model to a new sample of data, and when feasible should always be the first choice for the method of model validation; internal validation, where the predictive as well as the explanatory accuracy can be determined by first fitting your model to a subset of the data and then applying your model to the data that you withheld from the model building process (Hayashi, 2000). The inclusion of the ASEAN+6 data set in this study serves as a cross validation device.

\subsection{Data Collection and Sampling (Secondary Data)}

This study employs secondary data as its main source of data collection. This is to obtain larger and higher-quality databases that would otherwise be difficult, if not impossible, for any individual researcher to collect discretely. This also allow for a high degree of validity and reliability on a population sample basis. In addition, to eliminate the common error of fallacy, the study will follow data collection techniques and sources from Bortolotti, Fantini, and Siniscalco (2003); Boubakri, Cosset, Debab, and Valéry (2009); Breen and Doyle (2013) as well as the treatment of missing values and outliers.

\subsection{Observation Periods and Sampling Selection}

The study will focus on ASEAN nations from 1988 to 2008 with the peak of the Asian financial crisis being the median point of the observation period. The observational period of study is limited from 1988 to 2008 due to the lack of the availability of the most consensually accepted data provided by the World Bank. Fortunately, this gives us the opportunity to study an indicative and symbolic period that is organic and endogenous to the ASEAN context. It captures pre- and post- Asian financial crisis eras with the median point of the observation period being the peak of the reform measures induced by the Asian financial crisis. This isolates the spillover effect from the subprime crisis from the US, the sovereign debt crisis 


\section{Macrothink}

from Europe, the trade war between China and US, and the global Covid19 crisis. The push for reforms post 2008 was not endogenous to the fiscal and public structural defects from the ASEAN region - but rather as policy responses to exogenous shocks coming from the western hemisphere.

The study will also use ASEAN+6 with the addition of China, Japan and South Korea, Australia, and New Zealand to the ASEAN group as a control group to cross validate the statistical findings.

\subsection{Model Specification}

Stage 1 - Probit Model: ASEAN, ASEAN+6

$\operatorname{PROPEN}_{-} \mathrm{t}(1,0)=c+b_{1} \mathrm{DEBT}_{-} / \mathrm{GDP}_{-\mathrm{t}}+b_{2} \mathrm{FDI}_{-} \mathrm{t} / \mathrm{GDP}_{-} \mathrm{t}+b_{3} \mathrm{GDPC}_{-\mathrm{t}}+b_{4} \mathrm{GDP}_{-}+b_{5}$ $\mathrm{INFLOG}_{-} \mathrm{t}+b_{6} \mathrm{TAX}_{-\mathrm{t}} / \mathrm{GDP}_{-} \mathrm{t}+b_{7} \mathrm{UNEM}_{-} \mathrm{t}+b_{8} \mathrm{IMF}_{-} \mathrm{t} / \mathrm{GDP}_{-} \mathrm{t}+b_{9} \mathrm{CAP}_{-} / \mathrm{GDP}_{-} \mathrm{t}+b_{10} \mathrm{TO}_{-} \mathrm{t}$ $/ \mathrm{GDP}_{-} \mathrm{t}+b_{11} \mathrm{TRADE}_{-} / \mathrm{GDP}_{-} \mathrm{t}+b_{12} \mathrm{ELEC}_{-\mathrm{t}}+b_{13} \mathrm{DEMO}_{-\mathrm{t}}+b_{14} \mathrm{LEGAL}_{-} \mathrm{t}+r$

Stage 2 - FE Regression Model: ASEAN, ASEAN+6

$\mathrm{REV}_{-} \mathrm{t} / \mathrm{GDP}_{-} \mathrm{t}=c+b_{1} \mathrm{DEBT}_{-} / \mathrm{GDP}_{-\mathrm{t}}+b_{2} \mathrm{FDI}_{-} / \mathrm{GDP}_{-}+b_{3} \mathrm{GDPC}_{-\mathrm{t}}+b_{4} \mathrm{GDP}_{\mathrm{t}}+b_{5}$ $\mathrm{INFLOG}_{-} \mathrm{t}+b_{6} \mathrm{TAX}_{-\mathrm{t}} / \mathrm{GDP}_{-} \mathrm{t}+b_{7} \mathrm{UNEM}_{-} \mathrm{t}+b_{8} \mathrm{IMF}_{-} \mathrm{t} / \mathrm{GDP}_{-} \mathrm{t}+b_{9} \mathrm{CAP}_{-} / \mathrm{GDP}_{-} \mathrm{t}+b_{10} \mathrm{TO}_{-} \mathrm{t}$ $/ \mathrm{GDP}_{-} \mathrm{t}+b_{11} \mathrm{TRADE}_{-\mathrm{t}} / \mathrm{GDP}_{-} \mathrm{t}+b_{12} \mathrm{ELEC}_{-\mathrm{t}}+b_{13} \mathrm{DEMO}_{-} \mathrm{t}+b_{14}$ LEGAL $_{-}+b_{15}$ PROPEN(Mediator Variable $)_{-} \mathrm{t}+r$

Where $c=$ constant;

$$
\begin{aligned}
& r=\text { residual } ; \\
& t=\text { time } ; \\
& b_{i}=\text { beta coefficients }_{i}
\end{aligned}
$$

Note. see Appendix A, table 1 for the operational definitions 


\section{MInstitute Macrothink}

\section{Research Findings}

\subsection{ASEAN Probit Model}

Table 1. Test of Model Effects: ASEAN

\begin{tabular}{lll}
\hline Parameter & Wald Chi-Squared & Sig. \\
\hline (Intercept) & 0 & 0.998 \\
DEBT & 0.918 & 0.338 \\
FDI & 0.002 & 0.962 \\
GDPC & 7.127 & $0.008^{* *}$ \\
GDP & 3.21 & 0.073 \\
INFLOG & 0.526 & 0.468 \\
TAX & 0.66 & 0.417 \\
UNEM & 0.13 & 0.718 \\
IMF & 0.586 & 0.444 \\
CAP & 8.555 & $0.003^{* *}$ \\
TO & 1.857 & 0.173 \\
TRADE & 8.448 & $0.004^{* *}$ \\
ELEC & 0.042 & 0.837 \\
DEMO & $\mathrm{a}$ & $\cdot$ \\
LEGAL & $\mathrm{a}$ &. \\
\hline
\end{tabular}

Note. $* *=p<0.05$, a. Unable to compute due to numerical problems

Table 1 presents the results for tests of model effects for the Probit model estimating the effects of the independent variables on the propensity to privatize. The variables that have a statistical significance value of less than 0.05 are considered to have a statistical effect on the propensity to privatization. Based on the estimator outputs, GDP per Capita, Stock Market Capitalization, and Current Account are the variables that statistically contribute to the propensity to privatize. IMF Annual Credit, Foreign Direct Investment, GDP growth, Inflation Rate, Tax Revenue, Unemployment Rate, National Debt, Stock Market Turnover, Election Year, Government Ideology, and the Legal System display no statistical effect on the propensity to privatize. This confirms that natural progression of the propensity to privatize in ASEAN is also being influenced by macro factors rather than merely a micro intra-enterprise managerial decision to optimize the enterprises' utility function. More interestingly, it is not the dynamics of the fiscal nor public affairs of ASEAN governments that trigger the decision to privatize. Fiscal and public affairs are the key theoretical foundation of privatization, but these variables were not part of the ASEAN governments' decision to privatize, according to the statistical findings. 
Table 2. Probit Parameter Estimates: ASEAN

\begin{tabular}{llll}
\hline Parameter & $B$ & Std. Error & Sig. \\
\hline (Intercept) & 5.258 & 7387.4374 & 0.999 \\
DEBT & 0.048 & 0.0504 & 0.338 \\
FDI & 0.004 & 0.0948 & 0.962 \\
GDPC & -0.024 & 0.0091 & $0.008^{* *}$ \\
GDP & 0.124 & 0.0691 & 0.073 \\
INFLOG & 0.181 & 0.2491 & 0.468 \\
TAX & -0.013 & 0.0162 & 0.417 \\
UNEM & -0.029 & 0.0792 & 0.718 \\
IMF & -0.01 & 0.0126 & 0.444 \\
CAP & 0.002 & 0.0007 & $0.003^{* *}$ \\
TO & 0.013 & 0.0093 & 0.173 \\
TRADE & 0.129 & 0.0444 & $0.004^{* *}$ \\
[Country=Brunei Darussalam] & -20.898 & 7929.8272 & 0.998 \\
[Country=Cambodia] & -5.67 & 5433.9136 & 0.999 \\
[Country=Indonesia] & 3.08 & 1.3048 & $0.018^{* *}$ \\
[Country=Lao PDR] & -6.227 & 7387.4373 & 0.999 \\
[Country=Malaysia] & 1.729 & 0.7532 & $0.022^{* *}$ \\
[Country=Myanmar] & -4.68 & 4566.5609 & 0.999 \\
[Country=Philippines] & 2.603 & 1.3219 & $0.049^{* *}$ \\
[Country=Singapore] & -16.232 & 7674.7999 & 0.998 \\
[Country=Thailand] & 4.604 & 1.5464 & $0.003^{* *}$ \\
[Country=Vietnam] & 2.441 & 1.457 & 0.094 \\
[ElectionYear=0] & 0.085 & 0.4163 & 0.837 \\
[ElectionYear=1] & $0^{\mathrm{a}}$ & $\cdot$ & $\cdot$ \\
[GovtIdeology=0] & $0^{\mathrm{a}}$ & $\cdot$ & $\cdot$ \\
[GovtIdeology=1] & $0^{\mathrm{a}}$ & $\cdot$ & $\cdot$ \\
[LegalSystem=0] & $0^{\mathrm{a}}$ & $\cdot$ & $\cdot$ \\
[LegalSystem=1] & $0^{\mathrm{a}}$ & $\cdot$ & $\cdot$ \\
(Scale) & $1^{\mathrm{b}}$ & &. \\
\hline
\end{tabular}

Note. ${ }^{* *}=p<0.05$, a. Set to zero because this parameter is redundant, b. Fixed at the displayed value

Table 2 presents the estimate of coefficients of the Probit model for ASEAN countries. The table shows that there is a statistical propensity to privatize in Indonesia, Malaysia, the Philippines, and Thailand. The major elements that contribute to the propensity to privatize in the identified countries include GDP per Capita, Current Account Balance, and Stock Market Capitalization at $\mathrm{p}<0.05$. The statistics seem to suggest that higher household income via higher GDP per capita, as a construct, reduce the needs to privatize public assets - a hybrid of a classical status quo and a laissez faire outcome - where "things are okay as is" and there is no gravitational push for changes or reforms by governments. The opposite is also true, lesser household income on a per capita basis tends to create the density for privatization. Although the findings on GDP per capita on a standalone basis is in line with the empirical literature, as well as the hypothesis (see Appendix A, table 2), the implication is very singular when a comprehensive range of other economic and fiscal variables are not statistically significant. On the economic and fiscal front, when GDP per capita is the only variable that is statistically robust, it implies that privatization as a reform measure seems to be more political than economic. Privatization might be deployed as a policy tools government uses to devise and conceive "change" when household income is stagnating to merely please voters. The statistics seems to present a case of "play politics," especially when economic stabilization 
variables such as the aggregate GDP, inflation, and unemployment rate, as well as the public and fiscal variables such as national debt and tax revenue, which are the foundational theories behind the invention as well as application of privatization, were not part of the decision to privatize. Intuitively, although GDP per capita is an economic variable, it was not primarily used for macroeconomic purposes because if it was, other economic and fiscal variables should be statistically significant as well. The conventional wisdom of optimizing the total welfare of a nation via Pareto improvement was not the trigger of ASEAN governments to privatize. Privatization may be a device used by ASEAN politicians as a policy response to please voters with GDP per capita as a gauge to monitor the voters' contentment, comparable to what was seen in Buchanan and Wagner (1997). Buchanan and Wagner (1997) argues that the paradigm shift that led to Keynesianism gave politicians the opportunity to use Keynesian stabilization policies to foster their own agendas and to please voters; for example, governments were able to increase public spending for political reasons without having to rely on raising politically costly taxes: this was all justified in the name of economic stabilization.

Another statistical element of privatization is Stock Market Capitalization. Higher stock market capitalization is associated with a higher rate of privatization, as indicated by the positive coefficient. The statistics here are rather intuitive, the procedural operations of privatization are customarily executed through the stock market. Hence, more developed stock market infrastructures measured by their size via market capitalization seems to manufacture the financial ecosystem needed to originate privatization deals.

The addition of the current account balance to the statistical significant realm is not novel here, it confirms the general theory of privatization under a quasi-market structure via New Public Management (NPM), where more seamless integrations between the private and public sector manifested by the openness of a country through higher flows of trade dictate the decision to privatize. Privatization was renowned as a legacy of Margaret Thatcher, in the United Kingdom, a developed nation where the formulation of more openness as well as efficient controlling mechanisms of a state via NPM originated. NPM registers more openness of economies and the flow from globalization helped to foster privatization.

On an organic progression basis, country-wise, the Probit model illustrates that Indonesia, Malaysia, the Philippines, and Thailand are statistically more likely to be involved in privatization in relation to the changes in GDP per capita, current account and stock market capitalization.

Furthermore, the coefficients readings are also in line with the hypotheses. To be more precise, the statistical reading suggests: for one unit of a reduction in GDP per capita, the propensity to privatize increased by 0.024 units; for one unit increase in stock market capitalization, the propensity to privatize increased by 0.002 units; and for an increase in 1 unit of current account as a percentage of GDP, the propensity to privatize increased by 0.129 units. 


\subsection{ASEAN+6 Probit Model}

Table 3. Test of Model Effects: ASEAN+6

\begin{tabular}{lll}
\hline Parameter & Wald Chi-Squared & Sig. \\
\hline (Intercept) & 0 & 0.995 \\
DEBT & 0.455 & 0.500 \\
FDI & 0.043 & 0.836 \\
GDPC & 7.289 & $0.007^{* *}$ \\
GDP & 3.908 & $0.048^{* *}$ \\
INFLOG & 1.147 & 0.284 \\
TAX & 0.448 & 0.503 \\
UNEM & 0.129 & 0.720 \\
IMF & 0.623 & 0.430 \\
CAP & 7.289 & $0.003^{* *}$ \\
TO & 1.267 & 0.26 \\
TRADE & 8.157 & $0.004^{* *}$ \\
ELEC & 0.455 & 0.500 \\
DEMO &. & $\cdot$ \\
LEGAL &. &. \\
\hline
\end{tabular}

Note. $* *=p<0.05$, a. Unable to compute due to numerical problems

Table 3 presents a summary from the test of model effects using ASEAN+6 nations. It examines the propensity of the countries to privatize vis-à-vis changes in its political, institutional, and economic determinants. The outputs indicated that the GDP, GDP per Capita, Stock Market Capitalization, and Current Account Balance have statistical effects on the propensity to privatize, at $\mathrm{p}<0.05$. The "Plus-Six" are generally more developed countries than the ASEAN counterparts, typically being frontier countries, and are used as a control group for cross-validation. The addition of the Plus-Six as a control group aims to increase the reliability of the findings through comparison of the two groups, in our case, ASEAN and ASEAN+6.

There was an addition of GDP to the statistical realm under the ASEAN+6 model. This suggests there is some degree of economic stabilization taken into account when the Plus-Six governments employed privatization, it was used as an economic counter cyclical device. This is in line with the empirical literature we saw from Schipke (2001); Bortolotti, Fantini, and Siniscalco (2003); Brune, Garrett, and Kogut (2004);(Meseguer (2004); Henisz, Zellner, and Guillen (2005). The statistical results confirm and cross-validate the uniqueness of the ASEAN context. 


\section{Macrothink}

Table 4. Probit Parameter Estimates: ASEAN+6

\begin{tabular}{|c|c|c|c|}
\hline Parameter & $B$ & Std. Error & Sig. \\
\hline (Intercept) & 5.088 & 7360.4092 & 0.999 \\
\hline DEBT & 0.034 & 0.0507 & 0.500 \\
\hline FDI & -0.02 & 0.0953 & 0.836 \\
\hline GDPC & -0.024 & 0.009 & $0.007 * *$ \\
\hline GDP & -0.028 & 0.0792 & $0.048^{* *}$ \\
\hline INFLOG & 0.271 & 0.2529 & 0.284 \\
\hline TAX & -0.011 & 0.0164 & 0.503 \\
\hline UNEM & 0.138 & 0.0698 & 0.720 \\
\hline IMF & -0.01 & 0.0128 & 0.430 \\
\hline CAP & 0.002 & 0.0007 & $0.003 * *$ \\
\hline TO & 0.011 & 0.0094 & 0.260 \\
\hline TRADE & 0.127 & 0.0446 & $0.004 * *$ \\
\hline [Country=Australia] & -26.701 & 7499.2134 & 0.997 \\
\hline [Country=Brunei Darussalam] & -21.485 & 7923.7184 & 0.998 \\
\hline [Country=Cambodia] & 4.437 & 5284.2407 & 0.999 \\
\hline [Country=China $]$ & 6.25 & 4281.2115 & 0.999 \\
\hline [Country=India] & -1.409 & 0.7843 & 0.072 \\
\hline [Country=Indonesia] & 2.933 & 1.3232 & $0.027 * *$ \\
\hline [Country=Japan] & -43.265 & 8645.8916 & 0.996 \\
\hline [Country=Korea] & -10.848 & 7610.775 & 0.999 \\
\hline [Country=Lao PDR] & -6.443 & 7360.4091 & 0.999 \\
\hline [Country=Malaysia] & 2.663 & 1.4003 & 0.057 \\
\hline [Country=Myanmar] & 0.036 & 8303.9832 & 1.000 \\
\hline [Country=New Zealand] & -21.119 & 7831.4558 & 0.998 \\
\hline [Country=Philippines] & 2.391 & 1.3418 & 0.075 \\
\hline [Country=Singapore] & -16.494 & 7614.3801 & 0.998 \\
\hline [Country=Thailand] & 4.229 & 1.4955 & $0.005^{* *}$ \\
\hline [Country=Vietnam] & 51.941 & 11987.982 & 0.997 \\
\hline [ElectionYear=0] & 0.283 & 0.4189 & 0.500 \\
\hline [ElectionYear=1] & $0^{\mathrm{a}}$ & . & 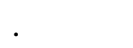 \\
\hline [GovtIdeology $=0$ ] & $0^{\mathrm{a}}$ & . & . \\
\hline [GovtIdeology=1] & $0^{\mathrm{a}}$ & . & . \\
\hline$[$ LegalSystem=0] & $0^{\mathrm{a}}$ & . & . \\
\hline [LegalSystem=1] & $0^{\mathrm{a}}$ & . & . \\
\hline (Scale) & $1^{\mathrm{b}}$ & & \\
\hline
\end{tabular}

Note. ${ }^{* *}=p<0.05$, a. Set to zero because this parameter is redundant, $\mathrm{b}$. Fixed at the displayed value

Table 4 presents the coefficients of the Probit model estimating the countries' propensity to privatize. Malaysia and the Philippines were dropped out of the statistically significant variable pact; Indonesia and Thailand are still statistically robust at $p<0.05$. The statistics seem to suggest that Thailand and Indonesia interacted more with their Plus-Six counterparts in relation to privatization.

In line with earlier models, increasing the nation's current account balance as well as the nation's stock market capitalization will increase the propensity of the country to privatize. Additionally, lower GDP per capita also induce the decision to privatize. More interestingly, there was an addition of GDP to the ASEAN+6 Probit model. The statistics seems to suggest that more developed governments, with the inclusion of the Plus-Six pact, employed privatization as a tool for economic stabilization. 
In general, GDP per capita, GDP, Stock Market Capitalization, and Current Account Balance are the only elements that are statistically significant in determining Indonesia's and Thailand's decision to privatize. The statistical resemblance confirms and cross-validate the findings with a more statistical clarity regarding the isolated effect of ASEAN context. Essentially the cross-validation technique confirms the uniqueness of the ASEAN context.

Furthermore, the coefficients readings of the ASEAN+ 6 are also line with the hypotheses. The statistics suggest: for one unit reduction in GDP per capita, the propensity to privatize increased by 0.024 units; for one unit reduction in GDP, the propensity to privatize increased by 0.028 units; for one unit increase in stock market capitalization, the propensity to privatize increased by 0.002 units; and for an increase in one unit of current account as a percentage of GDP, the propensity to privatize increased by 0.127 units.

\subsection{ASEAN FE Regression}

Table 5.1. FE Coefficients: ASEAN

\begin{tabular}{lllll}
\hline Parameter & Unstandardized Coefficients & Std. Error & $\mathrm{t}$ & Sig. \\
\hline (Constant) & 483.425 & 784.704 & 0.616 & 0.565 \\
DEBT & -50.36 & 33.883 & -1.486 & 0.197 \\
FDI & -48.79 & 78.531 & -0.621 & 0.562 \\
GDPC & -0.03 & 0.04 & -2.319 & $0.046^{* *}$ \\
GDP & 55.475 & 150.568 & 0.368 & 0.728 \\
INFLOG & 91.122 & 136.598 & 0.667 & 0.534 \\
TAX & -42.477 & 27.625 & -1.538 & 0.185 \\
UNEM & -22.949 & 143.556 & -0.16 & 0.879 \\
IMF & 6.888 & 12.123 & 0.568 & 0.594 \\
CAP & 6.371 & 3.84 & 2.39 & $0.041^{* *}$ \\
TO & 1.609 & 14.138 & 0.114 & 0.914 \\
TRADE & 26.31 & 10.478 & 2.511 & $0.033^{* *}$ \\
ELEC & -24.288 & 81.976 & -0.296 & 0.779 \\
DEMO & 114.808 & 123.134 & 0.932 & 0.394 \\
LEGAL & 82.527 & 126.562 & 0.652 & 0.543 \\
PROPEN (Mediator Var) & -0.01 & 0.034 & -0.28 & 0.791 \\
\hline
\end{tabular}

Note. $* *=p<0.05$

Table 5.2. R-Squared Summary: ASEAN

\begin{tabular}{lllll}
\hline $\mathrm{R}$ & $\mathrm{R}-$ Squared & Adjusted-R Squared & Std. Error & Sig. \\
\hline 0.885 & 0.784 & 0.520 & 110.82641 & $0.043^{* *}$ \\
\hline Note. ${ }^{* *}=p<0.05$ & & & &
\end{tabular}

Table 5.1 and 5.2 present the FE regression outputs that statistically estimates the explanatory power of determinants of the sensitivity of privatization for ASEAN countries. For the ASEAN countries, the regression output exhibits an adjusted R-squared of 0.52 , which indicates that $52.0 \%$ of variation in the scale of privatization can statistically be explained by the changes in the economic, political, and institutional variables. Its explanatory power is also statistically significant at $\mathrm{p}=0.043$. In addition, the statistical significance of the regression coefficients is in line with earlier findings, GDP per Capita, Current Account 


\section{Macrothink}

Journal of Public Administration and Governance

ISSN 2161-7104

2020, Vol. 10, No. 2

Balances, and Stock Market Capitalization are the only statistically significant variables in regulating the sensitivity of privatization. The statistical outputs are also in line with the hypotheses. To be more precise, for one unit of reduction in GDP per capita in US constant dollars, privatization revenue in million US constant dollars increased by 0.030 units; for an increase in one unit of current account as a percentage of GDP, privatization revenue in million US constant dollars increased by 26.310 units; and for an increase in one unit of stock market capitalization as a percentage of GDP, privatization revenue in million US constant dollars increased by 6.371 units.

The lower adjusted R-squared score is indicative of how the model frameworks were built based on the empirical studies, which primarily focus on aggregate data, throwing the ASEAN group into a big basket of all developed and developing countries from every parts of the world which do not display homogeneity to ASEAN nations' dynamics. More importantly, the foundation of the theoretical frameworks of privatization as an outgrowth of NPM has their origins from more developed nations. Hence, a lower adjusted R-square score among ASEAN nations is no surprise. Yet, in any case, an adjusted R-squared score of 52\%, objectively, is still statistically a convincing one.

\subsection{ASEAN+6 FE Regression}

Table 6.1. FE Coefficients: ASEAN+6

\begin{tabular}{lllll}
\hline Parameter & Unstandardized Coefficients & Std. Error & $\mathrm{t}$ & Sig. \\
\hline (Constant) & 12517.326 & 5850.867 & 2.139 & 0.085 \\
DEBT & 110.146 & 259.337 & 0.425 & 0.689 \\
FDI & 384.231 & 389.773 & 0.986 & 0.37 \\
GDPC & -0.535 & 0.629 & -0.85 & 0.434 \\
GDP & -1155.94 & 1009.538 & -1.145 & 0.304 \\
INFLOG & -655.89 & 924.767 & -0.709 & 0.51 \\
TAX & -171.645 & 175.317 & -0.979 & 0.373 \\
UNEM & -397.527 & 821.624 & -0.484 & 0.649 \\
IMF & -59.316 & 72.314 & -0.82 & 0.449 \\
CAP & 15.514 & 21.934 & 2.419 & $0.039^{* *}$ \\
TO & 37.14 & 45.656 & 0.813 & 0.453 \\
TRADE & 401.728 & 109.981 & 3.653 & $0.005^{* *}$ \\
ELEC & -136.362 & 537.391 & -0.254 & 0.81 \\
DEMO & -18.147 & 485.207 & -0.037 & 0.972 \\
LEGAL & -177.794 & 581.356 & -0.306 & 0.772 \\
PROPEN (Mediator Var) & 0.132 & 0.121 & 1.083 & 0.328 \\
\hline
\end{tabular}

Note. $* *=p<0.05$

Table 6.2. R-Squared Summary: ASEAN+6

\begin{tabular}{llcll}
\hline $\mathrm{R}$ & $\mathrm{R}-$ Squared & Adjusted-R Squared & Std. Error & Sig. \\
\hline 0.948 & 0.899 & 0.776 & 536.58819 & $0.003^{* *}$ \\
\hline Note. ${ }^{* *}=p<0.05$ & & & &
\end{tabular}

The sensitivity of privatization of ASEAN+6 countries in relation to its economic, political, and institutional determinants is illustrated by the FE regression model output in Table 6.1 
and Table 6.2. The statistics adequately explained the explanatory power of the independent political, institutional, economic variables. The adjusted R-squared of 0.776 , suggests that $77.6 \%$ of the variations in the sensitivity of privatization can be statistically explained by the changes in the political, institutional, economic predictor variables. The ANOVA test exhibits that the model is statistically significant at $\mathrm{p}=0.003$. The higher adjusted R-Squared score seems to be in line with the addition of more developed nations via the introduction of the Plus-Six group to the model, which statistically supported the statistical "model fit" as the formation of the theoretical constructs used in the model frameworks were built based on literature with the underlying empirical evidence and theoretical foundations from more developed nations. After all, the principal concept of privatization is an outgrowth from the NPM theories with has its origin from developed nations.

Additionally, only two variables display a statistical impact to the scale of privatization in the ASEAN+6 model. The coefficients for Stock Market Capitalization and Current Account Balances are the only variables statistically significant in explaining the variation of the sensitivity of privatization, at $\mathrm{p}<0.05$. With the addition of the Plus-Six nations, typically with much higher national development than their ASEAN counterparts, the GDP per capita statistical phenomenon becomes absent. Intuitively as well as statistically, the findings seem to suggest that there is a certain threshold of a country's development (this could be measured by total GDP, Gross National Product, as well as GDP per capita, and etc.) that once reached, the politics at play pertaining to the use privatization as a policy tool to devise 'change' becomes irrelevant.

The coefficients are also in line with the hypotheses, yet the degree of the sensitivity of the ASEAN+6 group differs significantly from the ASEAN counterparts - for an increase in one unit of current account as a percentage of GDP, privatization revenue in million US constant dollars increased by 401.728 units (15.27x (times) higher than that of the ASEAN model at 26.310); and for an increase in one unit of stock market capitalization as a percentage of GDP, privatization revenue in million US constant dollars increased by 15.514 units (2.44x (times) higher than that of the ASEAN model at 6.371). The statistical readings of the coefficients seem to suggest that the impact of the key variables is stronger in the case of ASEAN+6 than the ASEAN group. Intuitively, the sensitivity of privatization tends to rise in more developed macroclimate. Again, the cross-validation technique confirms the uniqueness of the ASEAN context, the ASEAN countries are statistically less sensitive to the variation of the determinants.

\section{Discussion}

Public measures and reforms implemented by governments, under the lens of New Public Management, to foster national development are widely extended to developing nations across the globe. Privatization was invented and became a common element in the modern economic and fiscal policy, more so among the developed nations under the New Public Management era. The governments of developing nations, as well as ASEAN nations, followed suit and turned to privatization as a leeway for development and the pursuit of privatization, which was exacerbated during the Asian financial crisis as part of the austerity 
packages enforced by the IMF. However, the organic and endogenous progression of privatization as a phenomenon in pre- and post- crisis era lacked research, precisely on the factors determining the decision to privatize as well as the sensitivity of it in relation to the different moving parts.

This study formulated its conceptual frameworks, the research questions, the research objectives, and the hypotheses from the existing literature and empirical studies conducted in various regions of the globe, as well as in aggregate. Notwithstanding, the empirical studies that are directed to the aggregate data alone may fail to diagnose the isolated phenomenon of the ASEAN context. The emphasis here hence is on ASEAN, and ASEAN+6 nations as a control group, especially under the formation of the ASEAN Economic Community (AEC) which has attempted to mimic that of the more developed regional integration we see in Europe via the European Union (EU). The keynote is to understand and examine the political, economic, and institutional determinants of privatization in Southeast Asian countries in order to better comprehend the natural progression of privatization and how to conduct policy settings, and create the necessary economic, political, and institutional conditions to foster and adopt privatization as part of a country's policy tool.

As much as the study is successful in addressing the research questions and objectives, there are a number of limitations associated to the study. Firstly, the observational period of the study is limited to period from 1988 to 2008 due to the lack of the availability of the most consensually accepted data from World Bank. Fortunately, this gives us the opportunity to study a period that captures pre- and post- Asian financial crisis eras with the median point at the peak of Asian financial crisis, while isolating the spillover effect from crises from the western hemisphere as the need for reforms post 2008 was not endogenous to the fiscal and public structural defects of the ASEAN governments. Secondly, capturing and quantitatively unifying the types of political regime, or even defining one among ASEAN nations, is very challenging, if not impossible as they display no homogenous set of standardized regimes. An authoritarian dictatorship regime oftentimes comes in disguise as democracy via vote buying, changing the rule of law, coups d'état. Fundamentally, every nation in ASEAN has its own unique political dynamics concerning how political parties and leaders dominate the political scene in their country, typically a long-term domination - a binary quantitative construct generally used in most studies is unfit for ASEAN context.

Based on the above limitations, once the post 2008 data became available, future studies in this field can include periods beyond 2008 to further study how the spillover effect from crises that originated from other parts of the world affected ASEAN policy makers' decision to privatize, as well as the sensitivity of privatization in relation to its political, institutional, economic counterparts. It will be a cognitive stimulation to see how ASEAN governments, through the use of privatization, respond to the series of exogenous shocks post 2008 on a statistical basis: the 2008 subprime crisis originated in the US, the sovereign debt crisis in the 2011 originated in the EU zone, the trade war between the US and China that began in 2018, and the global covid19 crisis that began in 2020. Moreover, the political, legal, and economic conditions of the globe, as well as individual nations have significantly changed since the 2008 global economic crisis. 
Future studies should also concentrate on widening the quantitative scope of how to define and go through the "rabbit hole" of how one shall classify and quantify the different types of political classifications and tactics different political parties and leaders used to dominate the political scene in their country. A binary type variable used in Beck et al. (2001); La Porta, Lopez-de-Silanes, and Shleifer (2008) is not optimal for quantifying the ASEAN political context. Widening the scope of the classifications and employing a categorical political variable may be more statistically appropriate to reflect the reality of the politics at play among ASEAN nations.

The present study successfully demonstrated statistically the determinants that contributed to the decision of ASEAN governments to privatize, as well as the sensitivity of privatization in relation to its determinants. The findings of the study are important remarks to the incremental understanding of privatization as a phenomenon especially with the addition of the ASEAN context to the empirical literature universe. It is also important to note that under the framework of the regional integration of the economies of ASEAN countries via the ASEAN Economic Community (AEC), it is important to understand the natural progression of privatization in ASEAN in an isolated context, as opposed to statistically bundling them in a broad basket of developed and developing nations from every parts of the world typically seen in prior empirical studies and literature. The study has established several novel insights that can be used to statistically explain and rationalize the propensity and the sensitivity of the privatization as a phenomenon in Southeast Asia. As such, the statistical outputs and its implications can be used by both the general public as well as policy makers to create a policy "roadmap" to foster the essential settings for privatization in ASEAN based on its economic, political, and institutional counterparts.

To be precise, steering public policies toward constructive openness to international trades, and directing the barometer towards keeping the current account in the positive, will help promote privatization activities. Moreover, the financial market dynamics are also important developing the infrastructure as well as the cultivating the ecosystem of the domestic financial markets, specifically focusing on the size or market capitalization - will help expand privatization activities in the ASEAN region. Essentially, the statistics seem to suggest focusing on "size" rather than on turnover.

These policies may sound like mundane generic policies somewhat unconnected to the core fundamental theories from the literature and empirical studies of privatization. Yet, the statistical implications from the ASEAN context do indicate that focusing on the "surplus" of the current account and "size" of market capitalization will provide the optimal setting that foster privatization activities among ASEAN nations.

In any case, it must be noted that not all ASEAN nations display homogenous level of economic, political, institutional dynamics; hence, the policy implications derived from this study must be viewed with precaution. All in all, all ASEAN nations may employ the statistical findings established in this study as a compass to embrace privatization, to a degree in a personalized manner, individually or collectively as an avenue to foster national development. 


\section{References}

Beck, N., \& Katz, J. N. (1995). What to do (and not to do) with Time-Series-Cross-Section Data in Comparative Politics. https://doi.org/10.2307/2082979

Beck, T., Clarke, G., Groff, A., Keefer, P., \& Walsh, P. (2001). New Tools in Comparative Political Economy: The Database of Political Institutions. https://doi.org/10.1093/wber/15.1.165

Beck, T., Demirgu, K. A., \& Levine, R. (1999). A New Database on Financial Development and Structure. World Bank Policy Research Working Paper.

Beck, T., Clarke, G., Groff, A., Keefer, P., \& Walsh, P. (2001). New Tools in Comparative Political Economy: The Database of Political Institutions. World Bank Economic Review, 15(1), 165-176. https://doi.org/10.1093/wber/15.1.165

Bertolotti, B., Fantini, M., \& Diniscalco, D. (2002). Privatization Around the World: Evidence from Panel Data.

Biglaiser, G., \& Brown, D. (2003). The Determinants of Privatization in Latin America. https://doi.org/10.2307/3219886

Biglaiser, G., \& Danis, M. A. (2002). Privatization and Democracy: The Effects of Regime Type in the Developing World. https://doi.org/10.1177/0010414002035001007

Biglaiser, G., \& Staats, J. (2010). Do Political Institutions Affect Foreign Direct Investment? A survey of U.S. Corporations in Latin America. https://doi.org/10.1177/1065912909331428

Boix, C. (1997). Privatizing the Public Business Sector in the Eighties: Economic Performance, Partisan Responses and Divided Governments. https://doi.org/10.1017/S0007123497000239

Boubakri, N., Cosset, J. C., Debab, N., \& Balery, P. (2009). The Dynamics of Foreign Direct Investment and Privatization: An Empirical Analysis. https://doi.org/10.7202/029781ar

Boubakri, N., Cosset, J. C., Debab, N., \& Balery, P. (2011). Privatization and Globalization: An Empirical Analysis. https://doi.org/10.2139/ssrn.2172955

Bortolotti, B., Fantini, M., \& Siniscalco, D. (2001). Privatization: Politics, Institutions, and Financial Markets. Emerging Markets. https://doi.org/10.1016/S1566-0141(01)00013-9

Bortolotti, B., Fantini, M., \& Siniscalco, D. (2003). Privatization Around the World: Evidence from Panel Data.

Breen, M., \& Doyle, D. (2013). The Determinants of Privatization: A Comparative Analysis of Developing Countries. https://doi.org/10.1080/13876988.2013.741439

Breen, M. (2010). Domestic Interests, International Bargaining and IMF Lending.

Brune, N., Garrett, G., \& Kogut, B. (2004). The International Monetary Fund and the Global Spread of Privatization. 
Brune, N. (2004). Privatization Around the World.

Brune, N., \& Garrett, G. (2000). The Diffusion of Privatization in the Developing World.

Buchanan, \& Wagner. (1997). A Theorist of Political Economy and Social Philosophy.

Carter, D. B., \& Signorino, C. S. (2010). Back to the Future: Modeling Time Dependence in Binary Data. https://doi.org/10.1093/pan/mpq013

Chinn, M. D., \& Ito, H. (2008). A New Measure of Financial Openness. https://doi.org/10.1080/13876980802231123

Corsetti, G., Pesenti, P., \& Roubini, N. (1999). What Caused the Asian Currency and Financial Crisis? https://doi.org/10.3386/w6834

Debab, N. (2011). Globalization and Privatization: Two Faces Coin.

Djankov, \& Murrell. (2000). The Determinants of Enterprise Restructuring in Transition : An Assessment of the Evidence. A World Free of Poverty series Washington, D.C.: World Bank Group. https://doi.org/10.1596/0-8213-4815-9

Doyle, D. (2010). Politics and Privatization: Exogenous Pressures, Domestic Incentives and State Divestiture in Latin America. https://doi.org/10.1017/S0143814X10000127

Doyle, D. (2012). Pressures to privatize? The IMF, Globalization, and Partisanship in Latin America. https://doi.org/10.1177/1065912911411100

Dornbusch, R., Park, Y., \& Claessens, S. (2000, 2014). Contagion: Understanding How It Spreads. https://doi.org/10.1093/wbro/15.2.177

D'Souza, J., \& Megginson, W. L. (2000). The Financial and Operating Performance of Privatized Firms During the 1990s. https://doi.org/10.1111/0022-1082.00150

Faure-Grimaud, A. (1999). Using Stock Price Information to Regulate Firms, LSE. Mimeo.

Feigenbaum, H., \& Henig, J. (1994). The Political Underpinnings of Privatization : A Typology. World Politics. https://doi.org/10.2307/2950672

Feigenbaum, H., \& Hamnett. (1998). Shrinking the State: The Political Underpinnings of Privatization. Cambridge University Press. https://doi.org/10.1017/CBO9780511660016

Garrett, G. (1998). Global Markets and National Politics: Collision Course or Virtuous Circle? https://doi.org/10.1162/002081898550752

Gbakou, Jallab, \& Sandretto. (2008). Foreign Direct Investment, Macroeconomic Instability and Economic Growth in MENA Countries. UNDP African Trade Policy Centre Work.

Grossman, S. (1976). On the Efficiency of Competitive Stock Markets Where Traders have Diverse Information. https://doi.org/10.1111/j.1540-6261.1976.tb01907.x

Guislain, P. (1997). The Privatization Challenge. https://doi.org/10.1596/0-8213-3736-X 


\section{Macrothink}

Journal of Public Administration and Governance ISSN 2161-7104 2020, Vol. 10, No. 2

Gupta, N. (2008). Privatization in South Asia, in: G. Roland (Ed.) Privatization, Successes and Failures. https://doi.org/10.7312/rola14160-008

Gwartney, J., Lawson, R., \& Norton, S. (2008). Economic Freedom of the World: 2008 Annual Report.

Haque, M. S. (1998). New Directions in Bureaucratic Change in Southeast Asia: Selected Experiences. Journal of Political and Military Sociology, 26(1).

Haque, M. S. (2002a). Globalization, New Political Economy, and Governance: A Third World Viewpoint. Administrative Theory \& Praxis, 24(1). https://doi.org/10.1080/10841806.2002.11029352

Haque, M. S. (2002b). Structures of New Public Management in Malaysia and Singapore: Alternative Views. Journal of Comparative Asian Development, 1(1). https://doi.org/10.1080/10841806.2002.11029352

Hayashi, F. (2000). Econometrics.

Heckman, J. J. (1979). Sample Selection Bias as a Specification Error. https://doi.org/10.2307/1912352

Henisz, W. J., Zelner, B. A., \& Guille'n, M. F. (2005). The Worldwide Diffusion of Market-Orientated Infrastructure Reform 1977-1999. https://doi.org/10.1177/000312240507000601

Holmstrom, B., \& Tirole, J. (1993). Market Liquidity and Performance Monitoring. https://doi.org/10.1086/261893

Jensen, N. M. (2008). Political Regimes and Political Risk: Democratic Institutions and Expropriation Risk for Multinational Investors.

Jensen, M., \& Meckling, W. R. (1996). Theory of the Firm: Managerial Behavior, Agency Costs, and Ownership Structure.

Jones, S., Megginson, W. L., Nash, R., \& Netter, J. (1999). Share Issue Privatizations as Financial Means to Political and Economic Ends. https://doi.org/10.1016/S0304-405X(99)00021-5

Laffont, \& Tirole. (1993). A Theory of Incentives in Procurement and Regulation.

Lane, D. (2015). Introduction to Statistics, Rice University, University of Houston. http://onlinestatbook.com/online_Statics_Eduction.

La Porta, R., Lo'pez-de-Silanes, F., Shleifer, A., \& Vishny, R. W. (1997). Legal Determinants of External Finance. https://doi.org/10.3386/w5879

La Porta, R., Lo'pez-de-Silanes, F., Shleifer, A., \& Vishny, R. W. (1998). Law and Finance. https://doi.org/10.1086/250042

La Porta, R., Lo'pez-de-Silanes, F., Shleifer, A., \& Vishny, R. W. (1999). The Quality of 
Government. https://doi.org/10.3386/w6727

La Porta, R., Lo'pez-de-Silanes, F., \& Shleifer, A. (2001). Government Ownership of Commercial Banks. Mimeo. https://doi.org/10.3386/w7620

La Porta, R., Lo'pez-de-Silanes, F., \& Shleifer, A. (2008). The Economic Consequences of Legal Origins. https://doi.org/10.3386/w13608

McAllister, Studle, \& Ascui. (1990). Privatization and the Britain Electorate : Microeconomic Policies, Macroeconomic Evaluation, and Party Support. American Journal of Political Science. https://doi.org/10.2307/2111472

Megginson, W. L., \& Boutchkova, M. K. (2000). Privatization and the Rise of Global Capital Markets. https://doi.org/10.2139/ssrn.237408

Megginson, W. L., \& Netter, J. (2001). From State to Market: A Survey of Empirical Studies on Privatization. https://doi.org/10.2139/ssrn.262311

Megginson, W. L., Nash, R. C., Netter, J. M., \& Poulsen, A. B. (2000). The Choice Between Private and Public Markets: Evidence from Privatizations. https://doi.org/10.2139/ssrn.289882

Megginson, W. L. (2017). Privatization Trends and Major Deals in 2015 and 2016. http://dx.doi.org/10.2139/ssrn.2944287

Meseguer, C. (2004). What Role for Learning? The Diffusion of Privatization in OECD Countries and Latin American Countries. Journal of Public Policy. https://doi.org/10.1017/S0143814X04000182

Monnet, G., Mustapha, S. J., \& René, S. (2008). Foreign Direct Investment, Macroeconomic Instability and Economic Growth in MENA Countries.

Pagano, M. (1993). The Flotation of Companies on The Stock Market: A Coordination Failure Model. https://doi.org/10.1016/0014-2921(93)90111-M

Painter, M. (2004). The Politics of Administrative Reform in East and Southeast Asia: From Gridlock to Continuous Self Improvement? https://doi.org/10.1111/j.0952-1895.2004.00250.x

Perotti, E. C. (1995). Credible privatization.

Perotti, E., \& Van Oijen, P. (2001). Privatization, Political Risk, and Stock Market Development in Emerging Economies. https://doi.org/10.1016/S0261-5606(00)00032-2

Pollitt, C. (1995). Justification by Works or By Faith? Evaluating the New Public Management. Evaluation. https://doi.org/10.1177/135638909500100202

Pollitt, C. (1999). Integrating Financial Management and Performance Management. Paris, OECD, PUMA/SMO(99)4/FINAL.

Pollitt, C. (2002). Clarifying Convergence: Striking Similarities and Durable Differences in Public Management Reform. Public Management Review. 
https://doi.org/10.1080/14616670110071847

Pollitt, C., \& Bouckaert, G. (2003). Evaluating Public Management Reforms: An International Perspective, Evaluation in Public-Sector Reform: Concepts and Practice in International Perspective. Cheltenham, Edward Elgar.

Pollitt, C., \& Bouckaert, G. (2004, $2^{\text {nd }}$ ed.). Public Management Reform: A Comparative Analysis. Oxford, Oxford University Press.

Pollitt, C., Talbot, C., Caulfield, J., \& Smullen, A. (2004). Agencies: How Governments Do Things Through Semi-Autonomous Organizations. Basingstoke, Palgrave/Macmillan.

Pollitt, C., Van Thiel, S., \& Homburg, V. (2007). New Public Management in Europe: Adaptations and Alternatives. Basingstoke Palgrave MacMillan. https://doi.org/10.1057/9780230625365

Spiegel, \& Spulber. (1997). Capital Structure with Countervailing Incentives. Rand Journal of Economic. https://doi.org/10.2307/2555937

Sagarik, D. (2015). The Determinants of foreign Direct Investment Flows: Evidences from ASEAN Member Countries. NIDA Development Journal, 55/2.

Samaratunge, R., Alam, Q., \& Teicher J. (2008). The New Public Management Reforms in Asia: A Comparison of South and Southeast Asian Countries. International Review of Administrative Science. https://doi.org/10.1177/0020852307085732

Savas, E. S. (2000). Privatization and Public-Private Partnerships. SAGE Publications.

Schipke. (2001). Why Do Governments Divest? The Macroeconomics of Privatization. Springer-Verlag Berlin Heidelberg. https://doi.org/10.1007/978-3-642-56682-0

Shahbah, \& Hammoudeh. (2017). Is Globalization Detrimental to Financial Development? Further Evidence From a Very Large Emerging Economy with Significant Orientation Towards Policies. https://doi.org/10.1080/00036846.2017.1324615

Smullen, A. (2007). Translating Agency Reform: Rhetoric and Culture in Comparative Perspective. Rotterdam, Doctoral Dissertation.

Stiglitz. (2009). Moving Beyond Market Fundamentalism to a More Balanced Economy. International Congress of CIRIEC. https://doi.org/10.1111/j.1467-8292.2009.00389.x

Turner, M. (2002). Decentralization Facilitation. Journal of Public Administration and Development.

Van Thiel, S., \& Leeuw, F. (2002). The Performance Paradox in the Public Sector. Public Performance and Management Review, 25(3). https://doi.org/10.2307/3381236

World Bank. (1995). Bureaucrats in Business: The Economics and Politics of Government Ownership.

World Bank. (2015). World Bank Privatization Database. 


\section{Appendix}

Appendix A: Operational Definitions, Hypotheses

Table 1. Operational Definitions

\begin{tabular}{|c|c|c|c|}
\hline Variables & Operational Definitions & Units of Measurements & Abbreviations \\
\hline 1. Inflation $(\log )_{-} \mathrm{t}$ & $\begin{array}{l}\text { Annual change in consumer price index based } \\
\text { on constant local currency in country } \mathrm{i} \text { in year } \mathrm{t}\end{array}$ & $\log$ & INFLOG \\
\hline $\begin{array}{l}\text { 2. GDP growth } \\
(\%)_{-} \mathrm{t}\end{array}$ & $\begin{array}{c}\text { Annual percentage growth rate of gross } \\
\text { domestic product based on constant local } \\
\text { currency in country } \mathrm{i} \text { in year } \mathrm{t}\end{array}$ & Percentage & GDP \\
\hline $\begin{array}{l}\text { 3. GDP per } \\
\text { Capita_t }_{t}\end{array}$ & $\begin{array}{l}\text { Gross domestic product in constant US dollars } \\
\text { to total population in country } \mathrm{i} \text { in year } \mathrm{t}\end{array}$ & US dollars & GDPC \\
\hline $\begin{array}{l}\text { 4. Unemployment } \\
\text { Rate }(\%)_{\mathrm{t}}\end{array}$ & Unemployment rate in country $\mathrm{i}$ in year $\mathrm{t}$ & Percentage & UNEM \\
\hline $\begin{array}{l}\text { 5. Stock Market } \\
\text { Capitalization } \_t \\
\text { GDP }_{-} \text {/ }\end{array}$ & $\begin{array}{l}\text { Stock market capitalization to gross domestic } \\
\text { product in country } \mathrm{i} \text { in year t. Stock market } \\
\text { capitalization in year } \mathrm{t} \text { is calculated as the } \\
\text { average between the end-of-year market } \\
\text { capitalization deflated by the end-of-year } \\
\text { consumer price index }\end{array}$ & Ratio & CAP \\
\hline $\begin{array}{l}\text { 6. Stock Market } \\
\text { Turnover_t } / \text { GDP_t }\end{array}$ & $\begin{array}{l}\text { Stock market total value traded to gross } \\
\text { domestic product in a country } \mathrm{i} \text { in year } \mathrm{t}\end{array}$ & Ratio & TO \\
\hline $\begin{array}{l}\text { 7. National Debt }{ }_{-} / \\
\text {GDP }_{-t}\end{array}$ & $\begin{array}{l}\text { Total public debt as a percentage of gross } \\
\text { domestic product of country i in year t. It } \\
\text { includes domestic debt (such as debt held by } \\
\text { monetary authorities, deposit money banks, } \\
\text { nonfinancial public enterprises, and } \\
\text { households) and foreign debt (such as debt to } \\
\text { international development institutions) }\end{array}$ & Ratio & DEBT \\
\hline $\begin{array}{l}\text { 8. Tax Revenue } \text { Rt }_{t} / \\
\text { GDP }_{-t}\end{array}$ & $\begin{array}{c}\text { Total revenues from tax collection to gross } \\
\text { domestic product in country i in year } \mathrm{t}\end{array}$ & Ratio & TAX \\
\hline 9. Election $\_t$ & $\begin{array}{c}\text { Dummy variable taking the value } 1 \text { on the year } \\
\text { of a country's election years, and zero } \\
\text { otherwise. }\end{array}$ & Value 1,0 & ELEC \\
\hline $\begin{array}{l}\text { 10. Government } \\
\text { Ideology_t }\end{array}$ & $\begin{array}{c}\text { Dummy variable taking value } 1 \text { for years the } \\
\text { country is under a democratic regime, and } 0 \\
\text { otherwise }\end{array}$ & Value 1,0 & DEMO \\
\hline 11. Legal System_t & $\begin{array}{c}\text { Dummy variable taking value } 1 \text { for common } \\
\text { law system, and } 0 \text { otherwise }\end{array}$ & Value 1,0 & LEGAL \\
\hline $\begin{array}{l}\text { 12. Foreign Direct } \\
\text { Investment }{ }_{t} / \\
\text { GDP }_{-} \text {t }\end{array}$ & $\begin{array}{l}\text { Foreign direct investment (FDI) is measured as } \\
\text { the ratio of FDI inflows and FDI outflows to } \\
\text { gross domestic product in country i in year t }\end{array}$ & Value 1,0 & FDI \\
\hline
\end{tabular}




\begin{tabular}{|c|c|c|c|}
\hline $\begin{array}{l}\text { 13. Current } \\
\text { Account }_{-} \text {/ GDP }{ }_{-} \mathrm{t}\end{array}$ & $\begin{array}{c}\text { Current Account Balance to gross domestic } \\
\text { product in country i in year } \mathrm{t}\end{array}$ & Ratio & TRADE \\
\hline $\begin{array}{l}\text { 15. IMF's Annual } \\
\text { Credit }_{-} \text {/ GDP }{ }_{-} t\end{array}$ & $\begin{array}{l}\text { IMF's outstanding credit to gross domestic } \\
\text { product in country i in year t }\end{array}$ & Ratio & IMF \\
\hline $\begin{array}{l}\text { Privatization } \\
\text { Revenue_t }_{-} / \mathrm{GDP}_{\mathrm{t}}\end{array}$ & $\begin{array}{l}\text { Total revenues from privatization to gross } \\
\text { domestic product in country i in year t. Total } \\
\text { revenues are revenues in current US dollars } \\
\text { from total privatization deals (public offers and } \\
\text { private sales). gross domestic product is } \\
\text { expressed in current US dollars }\end{array}$ & Ratio & REV \\
\hline $\begin{array}{l}\text { Privatization } \\
\text { Propensity_t }\end{array}$ & $\begin{array}{l}\text { A binary variable capturing a country's } \\
\text { propensity to privatize. The value } 1 \text { is assigned } \\
\text { if there is at least one privatization deal in } \\
\text { country } i \text { in year } t \text {; the value } 0 \text { is assigned if } \\
\text { there is no privatization deal in country } i \text { in } \\
\text { year } t\end{array}$ & Value 1,0 & PROPEN \\
\hline
\end{tabular}




\section{Macrothink}

Journal of Public Administration and Governance

ISSN 2161-7104 2020, Vol. 10, No. 2

Table 2. Hypotheses

\begin{tabular}{|l|l|l|}
\hline Macroeconomics Implications & Hypotheses & Sign \\
\hline 1. Inflation $(\log )_{-} \mathrm{t}$ & $\begin{array}{l}\text { H1.1 Ceteris paribus, countries with lower inflation rate should be } \\
\text { associated with higher privatization revenue. }\end{array}$ & - \\
\hline 2. GDP growth $(\%)_{-} \mathrm{t}$ & $\begin{array}{l}\text { H1.2 Ceteris paribus, countries with lower GDP growth rate } \\
\text { should be associated with higher privatization revenue. }\end{array}$ & - \\
\hline 3. GDP per Capita_t & $\begin{array}{l}\text { H1.3 Ceteris paribus, countries with lower GDP per capita should } \\
\text { be associated with higher privatization revenue. }\end{array}$ & - \\
\hline 4. Unemployment Rate $(\%) \_t$ & $\begin{array}{l}\text { H1.4 Ceteris paribus, countries with higher unemployment rate } \\
\text { should be associated with higher privatization revenue. }\end{array}$ & + \\
\hline
\end{tabular}

\begin{tabular}{|l|l|l|}
\hline Stock Market Implications & Hypotheses & Sign \\
\hline 5. Stock Market Capitalization_t $/$ GDP_t & $\begin{array}{l}\text { H2.1 Ceteris paribus, countries with more liquid (domestic) stock } \\
\text { markets should be associated with a higher privatization revenue. }\end{array}$ & + \\
\hline 6. Stock Market Turnover ${ }_{-} / \mathrm{GDP}_{-} \mathrm{t}$ & $\begin{array}{l}\text { H2.2 Ceteris paribus, countries with higher stock market turnover } \\
\text { rate should be associated with a higher privatization revenue. }\end{array}$ & + \\
\hline
\end{tabular}

\begin{tabular}{|l|l|l|}
\hline Public Finance Implications & Hypotheses & Sign \\
\hline 7. National Debt_t $/$ GDP_t & $\begin{array}{l}\text { H3.1 Ceteris paribus, a financial distressed government (higher } \\
\text { national debt) should be associated with higher privatization } \\
\text { revenue. }\end{array}$ & + \\
\hline 8. Tax Revenue_t $/$ GDP_t & $\begin{array}{l}\text { H3.2 Ceteris paribus, lower tax revenue should be associated with } \\
\text { higher privatization revenue. }\end{array}$ & - \\
\hline
\end{tabular}

\begin{tabular}{|l|l|l|}
\hline Political Preference Implications & Hypotheses & Sign \\
\hline 9. Election_t & $\begin{array}{l}\text { H4.1 Ceteris paribus, an election year is less likely to induce } \\
\text { privatization, and it should be associated with less privatization } \\
\text { revenue.. }\end{array}$ & - \\
\hline 10. Government Ideology_t & $\begin{array}{l}\text { H4.2 Ceteris paribus, a country with a democratic government is } \\
\text { more likely to privatize, and it should be associated with higher } \\
\text { privatization revenue. }\end{array}$ \\
\hline 11. Legal System_t & $\begin{array}{l}\text { H4.3 Ceteris paribus, a country with a common law system is more } \\
\text { likely to privatize, and it should be associated with higher } \\
\text { privatization revenue. }\end{array}$ & + \\
\hline
\end{tabular}




\begin{tabular}{|l|l|l|}
\hline $\begin{array}{l}\text { Globalization Implication (including } \\
\text { Institutions and Interest Group Theory) }\end{array}$ & Hypotheses & Sign \\
\hline 12. Foreign Direct Investment ${ }_{-} / \mathrm{GDP}_{-} \mathrm{t}$ & $\begin{array}{l}\text { H5.1 Ceteris paribus, higher FDI should be associated with higher } \\
\text { privatization revenue. }\end{array}$ & + \\
\hline 13. Current Account ${ }_{-} / \mathrm{GDP}_{\mathrm{t}}$ & $\begin{array}{l}\text { H5.2 Ceteris paribus, higher current account balance should be } \\
\text { associated with higher privatization revenue. }\end{array}$ & + \\
\hline 14. IMF's Annual Credit ${ }_{-} / \mathrm{GDP}_{\mathrm{t}}$ & $\begin{array}{l}\text { H6.1 Ceteris paribus, higher IMF's credit as a percentage of GDP } \\
\text { should be associated with higher privatization revenue. }\end{array}$ & + \\
\hline
\end{tabular}

\section{Copyright Disclaimer}

Copyright for this article is retained by the author(s), with first publication rights granted to the journal.

This is an open-access article distributed under the terms and conditions of the Creative Commons Attribution license (http://creativecommons.org/licenses/by/4.0/). 